\title{
16 'WHAT THEY CALL THAT IN THE WHITES?': NGIYAMPAA AND OTHER PLACENAMES IN A NEW SOUTH WALES NGURRAMPAA
}

\author{
Tamsin Donaldson
}

\section{INTRODUCTION $^{1}$}

"The world as we know it is in the last resort the words through which we imagine and name it.' David Malouf puts these words into the head of a fictional nineteenth-century lexicographer recalling his encounter with 'The Only Speaker of His Tongue' (Malouf 1985:69).

When I wrote a grammar of the Wangaaypuwan variety of Ngiyampaa, I began with a map of what my teachers called their ngurram-paa', their 'camp-world', captioned 'the area in which surviving Ngiyampaa speakers were born and for which they know placenames' (Donaldson 1980:xxix, see Map 1).

1 Many Ngiyampaa people helped to make this record of their placename heritage possible besides those whose contributions are mentioned in the text, either by sharing their time and their stories with me or by encouraging me to write and publish this record in this form, or both. Jeremy Beckett made his 1957 fieldnotes available. I am grateful to him and also to Ben Donaldson and John Stowell for comments on earlier drafts and to Jeannette Hope for detailed and fruitful discussion, and practical help resulting in the inclusion of Maps 3 and 4. Paul Stillwell kindly tested and enabled me to improve the representations of pronunciations. Winifred Mumford prepared the base maps which made Maps 2 and 3 possible and Margaret Tyrie computerised the 1980 s tables. Dymphna Clark made the facilities of Manning Clark House available and Rod Burstall generously contributed to the costs.

2 Except in quotations from sources which may have used different conventions, all indigenous language words in italics, including placenames, have been written according to the spelling and pronunciation system outlined at $\$ 2.1$.

L. Hercus, F. Hodges and J. Simpson, eds, The Land is a Map: placenames of Indigenous origin in Australia, 207-238. Canberra: Pandanus Books in association with Pacific Linguistics, 2002.

(C) T. Donaldson 


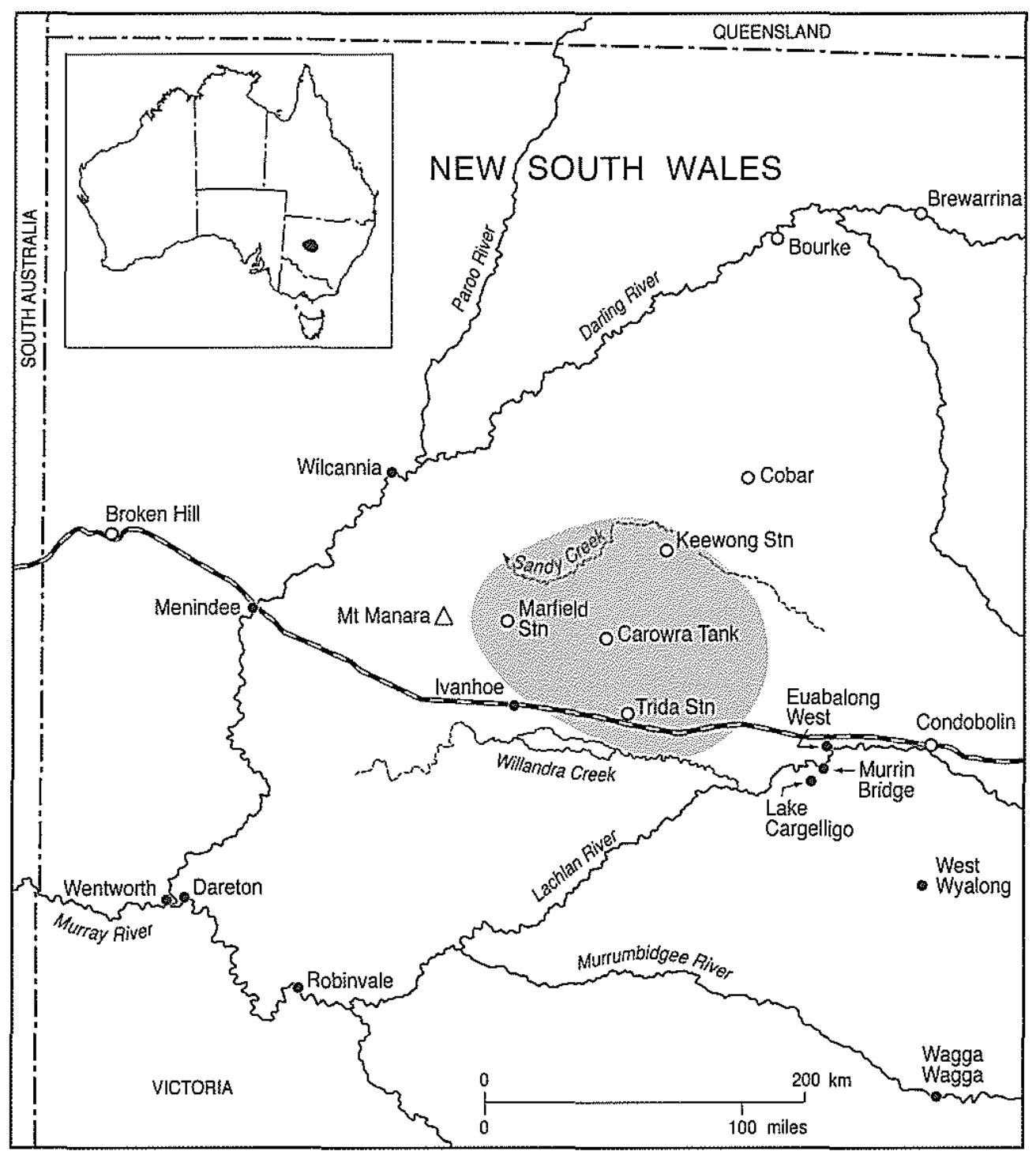

Map 1: The ngurrampaa, the 'campworld' in which the Ngiyampaa speakers who gave the placenames at Tables 1-4 were born, c.1900-1920. Based on Map 1, Donaldson (1997:iv). Cartographer: Kay Dancey 


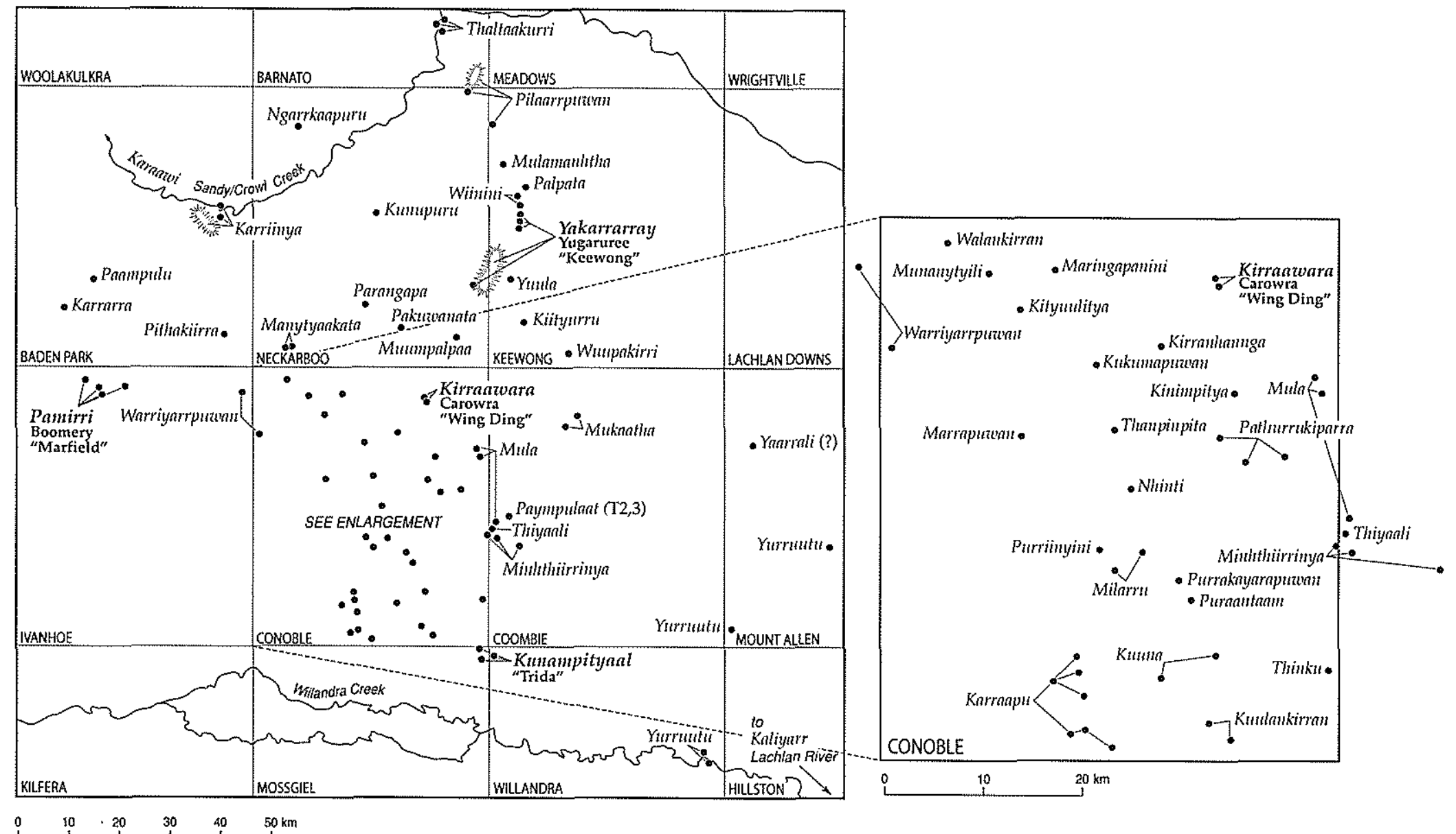

Map 2: Close-up of the ngurrampaa at Map 1. Ngiyampaa names are attached to physical features whose 1975 map names were recognised by my 1984 teachers as versions or replacements of Ngiyampaa names (see Table 1). Cartographer: Kay Dancey 
This paper presents these names and shows how they both reflected and shaped Ngiyampaa speakers' inherited 'camp-world' - and their sense of themselves. With respect to country, Aboriginal people often put the imaginary lexicographer's idea the other way round: the country does the speaking and the naming. While I was preparing this paper an Aboriginal interviewee from Queensland said on the ABC 'My country tells me who I am'. For the Ngiyampaa people of my teachers' generation, mostly born around 1900, your birthplace in the ngurrampaa named you, and your relations followed suit: Liza Kennedy said that her Uncle Red Tank called her 'nothing but' Wirrpinyi, the name of the place where she was born (see Table 3, 26).

My teachers learned placenames first of all through growing up 'camping about' in their ngurrampaa, walking from place to place, shifting camp, and 'taking notice' of their Elders. They had paid attention to conversations, songs, stories and performances, including the placenames that were 'sung out at the purrpa', the ceremonies held in 1914 to make boys into men. (For one life story, see Kennedy \& Donaldson 1982.) By the time I was learning the names from them, they were living mainly in the places marked with black dots on Map 1.

The paper also shows which Ngiyampaa placenames survived colonisation and in what forms, and some of the other re-naming strategies used by the newcomers. The changes were not all one way. Some of the new names were taken back into Ngiyampaa.

Nearly 90 Ngiyampaa placenames are presented in four tables followed by discussion. The paper concludes with some general questions about the relations between the Ngiyampaa names and naming practices and the names and naming practices of colonists and mapmakers ( $\$ 3-4)$. These are explored by reference to the tables $(\$ 2)$ and to material presented in Maps 1-4 and Figure 1 .

\section{PRESENTATION OF THE NAMES IN TABLES}

The names were recorded in 1984 or earlier from my Ngiyampaa teachers, Pilaarrkiyalu, 'Belar tree people', Ngiyampaa from the Keewong and Trida mobs, especially Liza Kennedy (Keewong), Archie King, Sarah Johnson and Mamie King (Trida). (The Marfield mob were Nhiilyikiyalu, 'Nelia tree people'.) Other people's particular contributions are acknowledged in the text and tables. I had been learning placenames incidentally, in the course of linguistic and related work, since 1972. In 1984, as well as reviewing names and information about them that I already knew, I systematically worked through all the names on all the 1975 Commonwealth Mapping Authority (CMA) 1:100 000 maps covering the ngurrampaa and surrounding country with Liza Kennedy and through some of them with others, usually at her suggestion. Though I had already travelled with some of my teachers in parts of the ngurrampaa, I was not able to visit the places named at the tables in their company in 1984 to enrich and refine our work, because of their increasing frailty.

By the end of 1984 Ngiyampaa people of the generations born around 1900 up until the end of the First World War had given equivalents 'in the whites' for more than 50 of the Ngiyampaa names they remembered. These names and their equivalents are presented at Tables 1 and 2 . The proportion of anglicised versions of the Ngiyampaa names to introduced names among the equivalents was about two to three. The equivalents for around 50 of the names (sometimes more than one per name) could be found on CMA 1:100 000 maps published in 1975. Map 2 locates the uses of these equivalents on the 1975 maps.

Ngiyampaa people did not know of any equivalents 'in the whites' for 30 more of their placenames, roughly two out of every five. They located the places they referred to as near or between other places named at Table 1, or not at all. These names are presented at Tables 2 and 3 . 
In a few cases (not listed), the reverse was the case, as with the 'Red Tank' after which Liza Kennedy's uncle was named. They knew that there was a Ngiyampaa name for a place but, in the absence of the previous generation to remind them of the name, they were now able to refer to it only by the English name they had grown accustomed to using instead.

In addition, they did not recognise any Ngiyampaa origin for many of the apparently Aboriginal names used on the 1975 maps. Figure 1 illustrates this in relation to a listing of all the names on one of the 1975 maps, Neckarboo. The 'Neckarboo' section of Map 2 shows the Ngiyampaa names that correspond to those underlined at Figure 1.

Material from the tables is referred to in the text by table and row number, for example T3, 26. Contents and conventions for the columns of Tables $1-4$ are as follows:

\subsection{Ngiyampaa name}

Column 1 gives the Ngiyampaa name (Tables 1-3) or asterisked reconstructed Ngiyampaa name (Table 4). The spelling system provides a guide to pronunciation. Each distinct sound in Ngiyampaa is written with a single letter or pair of letters. This is the full list of sounds:

$a, a a(a:), i, i i(i:), k(g), l, m, n, n g(\eta), n h, n y(n j), p(b), r(\mathcal{D}, r r(r), t(d), t h(d h), t y(d j), u, u u, w, y$

This is the system used since Johnson et al. (1982). Where different letters or symbols were used in Donaldson (1980), they follow their current equivalents in parentheses.

Words begin with these sounds: $k, m, n h, n g, t h, t y, w, y$; and finish with these sounds: $a, a a, i$, $i$, $l, n, r r, u, u u, y$.

The following pronunciation aids are used in Donaldson (1997:x):

VOWEL SOUNDS, AND HOW TO SAY THEM:

a like the underlined part of cut, love, touch

aa the same as $a$ but longer, like galah

$i \quad$ like tin, pretty

ii the same as $i$ but longer, like see, leaf, ski

$u \quad$ like putt, good

$u$ the same as $u$ but longer, like moon

CONSONANT SOUNDS AND HOW TO SAY THEM:

$k, p, t \quad$ always like school, spit, stop, or kick, pup, toot, never like cool, kick, pit, pup, top or toot

ng always like singer, never like finger

$n h \quad$ like nip, but put your tongue between your teeth as for thin

th like tin, but put your tongue between your teeth as for thin

$n h t h \quad$ like untie, but keep your tongue between your teeth for both sounds $n h$-th

ny always like canyon, never like many

ty like peach, but flatten your tongue against the roof of your mouth 
nyty like inch, but keep your tongue against the roof of your mouth for both sounds $n y-t y$ (imagine inych)

$r \quad$ like a Scottish pronunciation of Mary, marry

Say $l, m, n, p, r, t, w, y$, as you would in English words.

For phonological and phonetic details see Donaldson (1980). Stress is on the first syllable unless the second vowel is long as in Kirraawara at Table 1 (T1, 7). Hyphens separate analysable parts of names in this column, except at T1, 32 where the name is extra long.

Information on two names, Thipara (see Comment at T1, 10) and Muunkatha (see Comment at $\mathrm{T} 3,8$ ), was found too late for them to be listed as Ngiyampaa names in the first columns of these tables.

Some well-remembered Wongaaypuwan Ngiyampaa placenames, such as Kuparr meaning 'raddle' for Cobar and Kaliyarr, the Lachlan River, are not included in the tables, as being beyond the densely named ngurrampaa of the generation of my Pilaarrkiyalu teachers and the Nhiilyikiyalu they grew up with as neighbours. For discussion of the 'camp-worlds' of their birth (where their birthplaces are known) and of their 'drylander' childhoods spent 'camping about' in comparison to those of earlier generations, see $\$ 3.4$.

Mount Manara (Map 1) was not remembered by my teachers as being called Manaara, Manaarra or Manara. This may be because, as an important story place (as Mount Manara is for both Niyampaa and Paakantyi further west), it was not often appropriate to mention it by name. Fred Biggs, a generation older than my teachers, told Jeremy Beckett that it was not appropriate to mention the Being whose cave is at Mount Manara by name. He is now more openly named by people dealing with anglicised versions of his name, with spellings such as Baiami. Fred Biggs also told a story 'in language' 'from the very beginning' (marrathal-pu) about a journey 'to Mount Manara'. Jeremy Beckett thinks that the name, followed by $-k u$ meaning 'to', was said with its English pronunciation [mə'narə] (pers. comm. 2000). Therefore, Mount Manara, earlier spelt Manaro (Crotton n.d.) and Muneru (Town and Country Journal September 1871:304), is not included in the ngurrampaa, as defined for this study, at Map 1, nor is Manaara included at Table 1.

The representation of the ngurrampaa at Map 1 was made by shading so as to include all the physical features marked on 1975 maps named with recognised equivalents of Ngiyampaa names, not by mapping Ngiyampaa referents for Ngiyampaa names (see the end of \$3.1). A further 30-odd remembered names (from Tables 2 and 3) could not be mapped even in this roundabout fashion. Some of them may have referred to places outside this shaded area: Puru pinytyilanhi $(\mathrm{T} 3,18)$ is described as a 'tank on Keewong or Kaleno', where Keewong relations of Liza Kennedy camped during the first decade of the twentieth century, much further north (Map 3), and closer to Cobar (Donaldson 1985a:129).

\subsection{Literal meaning}

Names and parts of names which Ngiyampaa people recognised as meaningful are glossed in the columns headed 'Literal meaning' in Tables 1-4. No meanings differed from current meanings for the same forms. Thantaay pumanaarra $(\mathrm{T} 3,20)$ could have been translated 'frog(s) getting hit' or 'getting killed'. Only the translation 'frogs getting killed' was given.

Grammatically, the analysable names consist of nominal words and phrases, and/or phrases of other kinds, including fully explicit sentences $(\mathrm{T} 3,18)$. Nominal suffixes include ones deriving stems with the same reference as the root, such as -kirran 'big', but much more frequently ones deriving stems with a different reference, such as -pityaal 'with big', most commonly the plain 
comitative -puwan 'with' or 'having'. The comitative is the most frequently and readily recognisable placename element in today's anglicised map versions of placenames throughout the countries whose languages' names are formed by attaching the comitative of that language to its word for 'no!' - which include both Wangaaypuwan and Wayilwan varieties of Ngiyampaa and Wiradjuri (Donaldson 1985b) and the languages discussed by Ash (this volume). Early placename etymologists tend to record this suffix as meaning not 'with' or 'having' but 'place of' when it forms part of a placename.

Nominal roots refer most commonly to plants and their parts and products, body parts and products, and creatures.

\subsection{Pronunciation of equivalent name}

My teachers were able to answer each other's questions 'What they call that in the whites?' in respect of all the Ngiyampaa names at Table 1, sometimes with more than one name. Sometimes these names are anglicised versions of the Ngiyampaa name, sometimes they are quite different names. The 'pronunciation' columns in Tables 1,2 and 4 give a guide to the way Ngiyampaa people said that the names based on Ngiyampaa names are pronounced 'in the whites'. The columns also give a guide to the pronunciation of other names not obvious from the spelling, and of any names that have no English spelling known to me. I follow the conventions set out at the front of the Macquarie Dictionary (1981:46) for using symbols of the International Phonetic Alphabet to represent the phonemes of Australian English.

There are occasionally specifically Aboriginal characteristics in these pronunciations such as an initial /h/ $(\mathrm{T} 1,36)$ or omitted final /s/ $(\mathrm{T} 1,13)$, but otherwise the pronunciations appear to be the same as those of anyone else with long local experience. (A spot rather than comprehensive check was done in the area of Ivanhoe in 1984.) If two pronunciations are given, the more specifically Aboriginal one comes first $(\mathrm{T} 1,36)$. The pronunciation given at $\mathrm{T} 2,1$ contains the consonant cluster $/ \mathrm{nk} /$, fine midword in Ngiyampaa, but in most dialects of English only when a word is formed from two consecutive words (in 'turnkey' as opposed to 'monkey'). I was unable to find a map spelling for this name, or someone other than my teachers to pronounce it for me.

Using the Macquarie Dictionary conventions in 1984 (not always adequate to the task I was setting them), I recorded the first vowel of Boomery (Pamirri T1, 30) from Liza Kennedy as pronounced as in 'put', by contrast with that of Moolah (Mula T1, 21) as in 'pool'. I have not re-checked the Boomery pronunciation with either a Ngiyampaa or non-Ngiyampaa local.

\subsection{Spelling of equivalent name}

The spellings given in these columns in Tables 1,2 and 4 are those used on the 1975 CMA 1:100 000 map sheets named at Map 2. Sometimes there is more than one name, or more than one spelling of the same name on the maps. (Additional spellings from other, usually earlier, maps or sources are given in the 'Comment and information' columns.) Some of these spellings are used for more than one feature on the maps. No feature specifications are included in this column, except where the distinguishing part of the name plays an otherwise unintelligible adjectival role, as in Blue Tank (T1, 23), Pine Flat (T2, 3) and so on. For the reason why, see $\$ 3.1$.

Figure 1 shows the full range of named physical features on the map sheet 'Neckarboo'. On some of the other map sheets represented at Map 2, there are additional kinds of physical features, 
some named with equivalents of Ngiyampaa names, especially sidings etc. associated with the railway built to Roto $(\mathrm{T} 1,48)$ and as far as Trida $(\mathrm{T} 1,11)$ by 1919 .

\title{
2.5 Location
}

Table 2 has a column giving Ngiyampaa people's locations for places whose equivalent names 'in the whites' they know, but which are not represented on the 1975 map sheets at Map 2. Table 3 has a column giving Ngiyampaa people's locations for the places for which they know only Ngiyampaa names. These are usually given in terms of their position in relation to other places whose names do have mapped English equivalents, as listed at Table 1. (Pineflat Tank was found on 'Coombie' map sheet too late for Paympulaat (T2, 3) to be transferred to Table 1, but it appears at Map 2.)

\subsection{Comment and information}

The present tense is used in this column in Tables 1, 3 and 4 to attribute comments made in 1984. Placename information is included from A.L.P. Cameron (1899). He lived locally during the last couple of decades of the nineteenth century, first outside the ngurrampaa, at Moolbong, south of Willandra Creek, then at Murrumbong (Kuuna T1, 14) (Hope, Donaldson \& Hercus 1986:128-132 and 109 (Figure 8.1, partly reproduced here as Map 3)). He is interestingly clear about the limits of his language knowledge, but not about those of 'this part' (he writes from Murrumbong) and he did not attempt to map the names.

\subsection{Significance of place}

This column in Tables 1-3 gives examples of a range of kinds of Ngiyampaa associations with particular Ngiyampaa places. They include references, especially about swamp names and swamp 'owners', to Jeremy Beckett's fieldnotes (1957). He was recording mainly from people born in the 1880 s, in particular from Fred Biggs. Beckett gives this account of Biggs' information about swamp 'ownership':

\begin{abstract}
Every man 'owned' a series of (adjacent) swamps ... He shouted their names as he came onto the ceremonial ground and he might sometimes be addressed by the name of the most important one. He was not the sole 'owner' but he had the right to hunt in them and to give others the permission to do so, whereas hunting in another man's swamp necessitated giving the owner half the kill. In the only two cases Biggs could cite ... the swamps had been acquired from the father-in-law; however (they) ... could be acquired from one's father or mother's brother. (Beckett 1959:206)
\end{abstract}

There are also examples of songs 'in language' that include Ngiyampaa placenames. It was part of the song-making tradition to locate scenes or incidents celebrated in songs, often by reference to placenames, either in the songs themselves or in the stories told to enable people to appreciate the subtleties of their often cryptically allusive style. As long as such songs continued to be made in or travel into the ngurrampaa, placenames appeared in them, including new names (Dardanelles-ku, (war- $k u$ 'to war'), Ivanhoe (the races, and an indirect allusion to someone met there), Maitland (jail)). Since songs are often remembered with fondness by people who do not otherwise speak a great deal of their language, some placenames without mnemonic equivalents 'in the whites' have been preserved this way (Punpirrpuwan T3, 17). One song, which Mamie King taped for me in 
April 1981 at Murrin Bridge for deposit at the Australian Institute of Aboriginal and Torres Strait Islander Studies (AIATSIS), records two names: Kuluwarra (T3, 4) and Warriyarrpuwan (T1, 43). It was sung by Moolbong Johnson, a Wiradjuri clever man and song-maker who spent time at Carowra, but may have belonged to another, Scottie Lanky, who died before Mamie was born. (An unfamiliar Wiradjuri word may underlie tyingkatyi, which neither Mamie nor her elder sister Sarah Johnson was able to 'straighten out'.)

Kuluwarra-ku=thu manapi-y-aka.

K.-DAT=1NOM hunt-CM-IRR

I'll go hunting to Kuluwarra.

Ngathi $=t y u \quad$ yuwa-nga-y-aka mukaa Warriyarrpuwan-ti.

In that (place) $=1$ NOM sleep-EVENING-CM-IRR asleep W.-CIRC

That's where I might camp in the evening, at Warriyarrpuwan. (lit. lie asleep in W.)

Ka-yili-nya minkiyan.

Be-ULT.FOCUS-PRES degree.adverb

(I) am very selfish. (lit. (I) am focusing on others more, i.e. on preventing them joining me.)

Ngathu-para good man.

1+NOM-CATEG.ASSERT good man

I (am) truly a good man.

Wirrka-nha-kalay=tyu tyingkatyi.

limp-PRES-ONLY=1NOM [foot-CIRC?]

I just limp [(lame) in the foot?].

Ngaku=thu yana-nha.

to.that.(place) $=1 \mathrm{NOM} \quad$ go-PRES

That's where I'm going.

Shilling a day-ku Warriyarrpuwan-ku.

Shilling a day-DAT W.-DAT

For a shilling a day, to Warriyarrpuwan. [the shilling probably paid for rabbiting]

Abbreviations used here and elsewhere in the paper include CATEG.ASSERT categorical assertion; CIRC circumstantive; CM conjugation marker; CONT continued action; DAT dative; DU dual; IGNOR ignorative; IRR irrealis; LING.EVID linguistic evidence; NOM nominative; OBL oblique; PRES present; PURP purposive; ULT.FOCUS ulterior focus; 1 first person. Donaldson (1980:xxiii, 343 ) indexes the functions of all forms with upper case glosses. 
Table 1: Ngiyampaa names with known equivalents which appear on 1975 1:100 000 maps

\begin{tabular}{|c|c|c|c|c|c|c|}
\hline & $\begin{array}{l}\text { Ngiyampaa } \\
\text { name }\end{array}$ & $\begin{array}{l}\text { Literal } \\
\text { meaning }\end{array}$ & $\begin{array}{l}\text { Pronunciation } \\
\text { of equivalent } \\
\text { name }\end{array}$ & $\begin{array}{l}\text { Spelling of } \\
\text { equivalent } \\
\text { name }\end{array}$ & $\begin{array}{l}\text { Comment and } \\
\text { information }\end{array}$ & $\begin{array}{l}\text { Significance of } \\
\text { place }\end{array}$ \\
\hline 1 & Karaawi & & $/ \mathrm{kraul} /$ & $\begin{array}{l}\text { Sandy } \\
\text { Creek }\end{array}$ & $\begin{array}{l}\text { Crowl Creek on many } \\
\text { maps } \\
\text { Ngiyampaa prefer } \\
\text { 'Sandy Creek' }\end{array}$ & $\begin{array}{l}\text { Marks } \\
\text { approximate } \\
\text { northern extent } \\
\text { of my teachers } \\
\text { ngurrampaa as } \\
\text { defined here }\end{array}$ \\
\hline 2 & Karraa-pu & $\begin{array}{l}\text { don't-at } \\
\text { all } \\
\text { (Wait on!) }\end{array}$ & $\begin{array}{l}\text { /kə'noubəl/ } \\
\text { /kə'napu/ }\end{array}$ & Conoble & $\begin{array}{l}\text { Earlier spelt Canoble. } \\
\text { The Ngiyampaa name } \\
\text { comes from Manny } \\
\text { Johnson. Liza } \\
\text { Kennedy does not } \\
\text { know it, but recalls a } \\
\text { local Chinaman's } \\
\text { pronunciation, also } \\
\text { given here. see T4,4 }\end{array}$ & \\
\hline 3 & Karrarra & & /kər'are/ & Karrara & & $\begin{array}{l}\text { NB Not } \\
\text { Carowra }\end{array}$ \\
\hline 4 & Karriinya & & /kər'ınə/ & Corinya & & \\
\hline 5 & Kiityurru & & /gidzər'u/ & Gidgeroo & A government tank & \\
\hline 6 & Kinimpitya & & & $\begin{array}{l}\text { East } \\
\text { McDonalds } \\
\text { Tank }\end{array}$ & & \\
\hline 7 & $\begin{array}{l}\text { Kirraa- } \\
\text { wara }\end{array}$ & $\begin{array}{l}\text { leaves- } \\
\text { often with }\end{array}$ & /kər'aura/ & Carowra & $\begin{array}{l}\text { Earlier spelt Corowra. } \\
\text { Main government tank } \\
\text { in ngurrampaa. } \\
\text { Present homestead is } \\
\text { Wing Ding }\end{array}$ & $\begin{array}{l}\text { 'Old Parkes' } \\
\text { [Fred Biggs' } \\
\text { father-in-law's] } \\
\text { swamp' (Beckett } \\
\text { 1957:75). Site of } \\
\text { Carowra Tank } \\
\text { Aboriginal } \\
\text { Reserve. }\end{array}$ \\
\hline 8 & Kirranhannga & & & $\begin{array}{l}\text { West } \\
\text { McDonalds } \\
\text { Tank }\end{array}$ & & $\begin{array}{l}\text { Place of } 1914 \\
\text { purrpa }\end{array}$ \\
\hline 9 & Kityuulitya & & $\begin{array}{l}\text { /kədz'ulidzI/, } \\
\text { /kədz'uligə/ }\end{array}$ & Kajuligah & $\begin{array}{l}\text { Liza Kennedy (not } \\
\text { herself a reader) } \\
\text { recalls people saying } \\
\text { 'How do you spell } \\
\text { this? It's very hard?' }\end{array}$ & $\begin{array}{l}\text { Swamp of Fred } \\
\text { Biggs (Beckett } \\
\text { 1957:71) and } \\
\text { his 'boundary' } \\
(1957: 75)\end{array}$ \\
\hline
\end{tabular}




\begin{tabular}{|c|c|c|c|c|c|}
\hline $\begin{array}{l}\text { Kukuma- } \\
\text { puwan }\end{array}$ & $\begin{array}{l}\text { stumps- } \\
\text { with }\end{array}$ & $\begin{array}{l}\text { /tubara/ } \\
/ \text { tubo'ru/ }\end{array}$ & Tibora & $\begin{array}{l}\text { 'Tibora. Named from } \\
\text { high trees, climbed to } \\
\text { make observations' } \\
\text { (Cameron 1899). Also } \\
\text { pre-1901 } \\
\text { Cookenmabourne } \\
\text { (Map 4). Archie King } \\
\text { gives Thipara for } 2 \mathrm{nd} \\
\text { pronunciation, 'a } \\
\text { station } 40 \mathrm{~m} \text { from } \\
\text { Tiarra' }\end{array}$ & \\
\hline $\begin{array}{l}\text { Kunam- } \\
\text { pityaal }\end{array}$ & $\begin{array}{l}\text { turd-with } \\
\text { big }\end{array}$ & /'trarde/ & Trida & $\begin{array}{l}\text { 'Koonamgal. Dirty } \\
\text { place (a lot of } \\
\text { dung about)' } \\
\text { (Cameron 1899) }\end{array}$ & $\begin{array}{l}\text { Main camping } \\
\text { place of Trida } \\
\text { mob }\end{array}$ \\
\hline Kunu-puru & $\begin{array}{l}\text { sick of- } \\
\text { balls }\end{array}$ & /.kunə'bsrə/ & Koonaburra & & \\
\hline $\begin{array}{l}\text { Kuulan- } \\
\text { kirran }\end{array}$ & ?-big one & & Irish Lords & $\begin{array}{l}\text { Ngiyampaa mostly } \\
\text { say 'Irish Lord'. } \\
\text { '... named by its first } \\
\text { owner said to be the } \\
\text { son of an Irish Lord' } \\
\text { (Glover } 1989: 16 \text { ) }\end{array}$ & $\begin{array}{l}\text { 'Sung out at the } \\
\text { purrpa' } \\
\text { by Uncle Pluto } \\
\text { Williams, said } \\
\text { Sarah Johnson, } \\
\text { to show his } \\
\text { association with } \\
\text { the place. Song } \\
\text { about going to } \\
\text { Kuulankirran to } \\
\text { be counted }\end{array}$ \\
\hline Kuluna & & $/ \mathrm{m} \wedge \mathrm{rom}, \mathrm{boy} /$ & Munumbong & $\begin{array}{l}\text { 'Goonah. Grey water } \\
\text { snake'. 'Murrumbong. } \\
\text { Good place or good } \\
\text { game' (Cameron } \\
1899 \text { ). Cameron } \\
\text { appears to have } \\
\text { transferred the name } \\
\text { Murrumbong on } \\
\text { moving to a part of } \\
\text { Conoble from } \\
\text { Moolbong Stn, south } \\
\text { of Willandra Creek, } \\
\text { where there are tanks } \\
\text { named Murrumbong. } \\
\text { Ngiyampaa people say } \\
\text { the name is the } \\
\text { Wiradjuri word for } \\
\text { 'good' and pronounce } \\
\text { it marrumpaa, without } \\
\text { the Wiradjuri final ng }\end{array}$ & \\
\hline Manytyaakata & & $/$ mən'd $^{\prime}{ }^{2}$ eakətə/ & Munjagadah & $\begin{array}{l}\text { Cameron: } \\
\text { 'Munjackata A kind of } \\
\text { pipe clay' (white paint } \\
\text { is manha). Liza } \\
\text { Kennedy remembers a }\end{array}$ & \\
\hline
\end{tabular}




$\begin{array}{lll}16 & \text { Maringapanini } \\ 17 & \begin{array}{l}\text { Marra- } \\ \text { puwan }\end{array} & \\ 18 & \text { Milarru } & \end{array}$

$\begin{array}{lll}19 & \text { Minhthïninya } & \\ 20 & \text { Mulkaatha } & \\ 21 & \text { Mula pus } \\ 22 & \text { Mulamanhtha } & \end{array}$

23 Munanytyili, also Munanytyil wakaytyili

24 Muumpalpaa

25 Ngarrkaapuru

26 Nhinti

27 Paampulu

cassiaworld

?-balls

clitoris

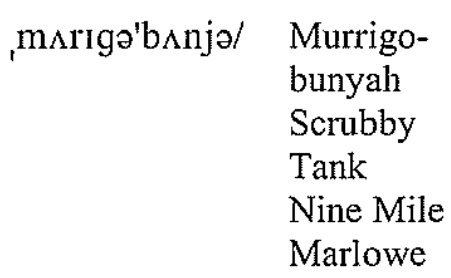

Mintinery

Wongram

Moolah

Blue Tank /,d $\Delta$ bolju'tri/

/nə'kabou/

/ninti/

/'bouka/

/av'ouka/

/'beəmbələ/ new selector changed the homestead name to Tasman. Then the tank name was changed to match (though not on the map)

Archie King Old Parkes' comments 'a big lake the other side of Marlowe, fills up when the rivers are flooded. They [Ngiyampaa people] call Marlowe Milarru too?' (half to one mile away)

Paddington Cameron: 'Milamanda lazy fellow'. Eliza Kennedy comments that mulamanhthiyi (ty $u$ ) means '(I) couldn't get there (to where I set out for)'. And mulamanhthaay (mayi) means '(person) who can't get there'. Such a person might be lazy 
/'jælək/

Yallock

/,buləbə'da/

Bulbadah

29 Palpata

$30 \quad$ Pamirri

/bumərI/

Boomery

Marfield

31 Parangapa

32 Pathurru-

kiparra

33 Pilaarr-

puwan

34 Pithakiirra

35 Puraantaam

36 Purrakayara- ?-with puwan

37 Purriinyini

38 Thaltaakurri

39 Thanpin- ?-balls

pita

40 Thinku

$41 \quad$ Thiyaali

42 Walan-

kirran /bə'ræyi,ba/

/'brinr,bal

/brinini/

/trl'tagari/

/til'tagera/

/hermijan/

/'ermijənz/

belah /bə'leərəbən/
trees-with

Berangabah

Mountain

Tank

Belarabon

Bithegera

Browns

Dam

Amiens

Borraninna

Tiltagara

(Lake etc)

Lambing

Camp

Tinco

wood

/tr'jहərə/

hard-big /,walən'giəra/

one
Cameron:

'Bugwanada Stunted pine with spreading

branches'. Eliza

Kennedy comments

'not many pine trees

around there, mostly

dense mallee'

Cameron: 'Boolbadah

Where a camp was

being made, but was

for some reason

abandoned'

Main camping

place of the

Marfield mob

Mamie King

thinks that

Kulangkirri was

ceremonially

'sung out' as the

e for (a

Yallock
Balarambone on an

early map

This is the name

Brown's Dam made to

'fit [Ngiyampaa]

mouths', except for

irregular final $m$

Eliza Kennedy recalls A swamp of

that 'Catholic people 'Old Parkes'

changed the black

name to Amiens',

presumably after

World War One

\section{Marfield mob camped}

there. Many spoke

Paakanytyi 'as well as

their own': cf.

Paakanytyi thiltakara

'permanent lake'

(Hercus 1993:120)

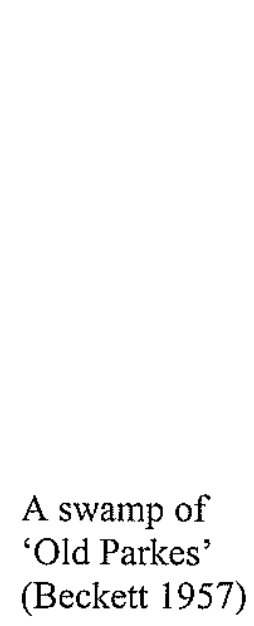




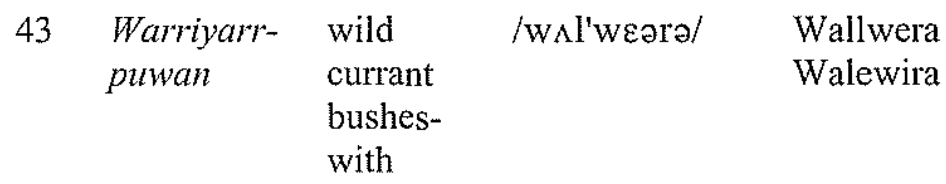

44 Wii-nini fire(wood) /'winin/

45 Wutpakirri - ?

46

Yaarrali

47

Yakarraray

48

Yurruutu

49

Yuula /jula/

Winnini
Obah
Yathong

/kiwoy/

/routou/

/
Ulah (swamp) (station, lake with dam etc.) Roto
Song where the singer heads there to earn 'shilling-a-day" (probably rabbiting)

c.f. *Wiiny-tyalapaa $\mathrm{T} 4,4$

Liza Kennedy comments "wulpa might have been a mouse of one kind or another' Donaldson (1980:317) Site of gives Yathong, corrected in 1984 to 'by Sandy Creek' whether as location of Yaarrali or story is not clear

Redbreast \& Waaway story (and/or by Karaawi)

(Donaldson 1980:317)

Yugaruree 'Yikarreri Stagnant Main camping green water'.

Keewong 'Keewong Where the moon camped' (Cameron 1899), 'moon' in Wiradjuri Liza Kennedy comments 'I don't know if the whites got it off the blacks or the blacks got it off the whites'. The Ngiyampaa regularly made English words beginning with $r$ "fit their mouths' by adding $y u$ - e.g. yurraapat 'rabbit'. Obviously Aboriginally derived names to the east begin with /ju/, e.g. Uranaway, Euabalong, from $y u$, sometimes ngu place of the Keewong mob 
Table 2: Ngiyampaa names with known equivalents which do not appear on 1975 1:100,000 maps

\begin{tabular}{|c|c|c|c|c|c|c|}
\hline & $\begin{array}{l}\text { Ngiyampaa } \\
\text { name }\end{array}$ & $\begin{array}{l}\text { Literal } \\
\text { meaning }\end{array}$ & $\begin{array}{l}\text { Pronunciation of } \\
\text { equivalent name }\end{array}$ & $\begin{array}{l}\text { Spelling of } \\
\text { equivalent } \\
\text { name }\end{array}$ & Location & Significance of place \\
\hline 1 & Kunu-kimpa & sick of-? & /,mungr'dzaira/ & None found & Near Trida & \\
\hline 2 & Paynparra & & & $\begin{array}{l}\text { Corner Pen } \\
\text { Tank }\end{array}$ & & \\
\hline 3 & Paympulaat & & & Pine Flat & $\begin{array}{l}\text { In Trida territory. } \\
\text { For Pine Flat } \\
\text { Tank, see Map } 2\end{array}$ & $\begin{array}{l}\text { Mamie King's } \\
\text { birthplace } \\
1918 \text { or } 1919\end{array}$ \\
\hline 4 & Pulparri & & /'bulberI/ & & & $\begin{array}{l}\text { Nickname of Harry } \\
\text { Kelly (brother of Jack) } \\
\text { who was born there }\end{array}$ \\
\hline 5 & Pultuparampa & & $\begin{array}{l}\text { /pu'lipə,rımpa/ } \\
\text { /pu'lupə,rımpə/ }\end{array}$ & & $\begin{array}{l}\text { Tank on } \\
\text { Marfield? } \\
\text { Perhaps near } \\
\text { Trangie Tank? }\end{array}$ & \\
\hline & Punhthita & & /bAn'ditt/ & & $\begin{array}{l}\text { Tank on Marfield } \\
\text { 'with ruiny hut' }\end{array}$ & \\
\hline
\end{tabular}

Table 3: Ngiyampaa names without known equivalents

\begin{tabular}{|c|c|c|c|c|}
\hline Ngiyampaa name & $\begin{array}{l}\text { Literal } \\
\text { meaning }\end{array}$ & Location & $\begin{array}{l}\text { Comment and } \\
\text { information }\end{array}$ & Significance of place \\
\hline 1 Kalpakalpaka-puwan & $\begin{array}{l}\text { taggy (trees)- } \\
\text { with }\end{array}$ & Near Murrumbong & $\begin{array}{l}\text { Liza Kennedy says kalpa } \\
\text { is a 'jutting tag on a } \\
\text { branchy tree' }\end{array}$ & \\
\hline 2 Kukum-puwan & erection-with & Near Keewong & & \\
\hline 3 Kulam-puwan & tree fork-with & Keewong area & $\begin{array}{l}\text { 'Koolagin forked sticks } \\
\text { stuck in the ground' } \\
\text { (Cameron 1899) }\end{array}$ & \\
\hline 4 Kulu-warra & seed pod-? & $\begin{array}{l}\text { A good crabhole or } \\
\text { gilgay by the back } \\
\text { gate on W-Tree, } \\
\text { between W-Tree and } \\
\text { Carowra }\end{array}$ & $\begin{array}{l}\text { Liza Kennedy recalls } \\
\text { "We used to camp there } \\
\text { often' }\end{array}$ & $\begin{array}{l}\text { Song starting } \\
\text { 'Kuluwarraku thu } \\
\text { manapiyaka', 'I'll go } \\
\text { hunting to Kuluwarra' }\end{array}$ \\
\hline Maki-minyi & raw-? & Near Murrumbong & & $\begin{array}{l}\text { Swamp of 'Old Parkes' } \\
\text { (Beckett 1957) }\end{array}$ \\
\hline 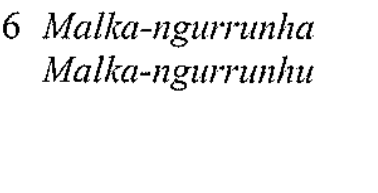 & mulga-crabhole & $\begin{array}{l}\text { A 'good holding' } \\
\text { crabhole not far from } \\
\text { Koonaburra on the } \\
\text { way to Carowra Tank }\end{array}$ & $\begin{array}{l}\text { Both ngurrunha and } \\
\text { ngurrunhu are usual for } \\
\text { 'crabhole' }\end{array}$ & \\
\hline Mukarr-kaa & $\begin{array}{l}\text { porcupine } \\
\text { grass-? }\end{array}$ & On Keewong & $\begin{array}{l}\text { Porcupine grass and all } \\
\text { burrs and prickly plants } \\
\text { are mukarr }\end{array}$ & \\
\hline
\end{tabular}


8 Mukarr-puwan

9 Muthaangkirri

10 Ngarrampa-puwan

11 Palapalaka-puwan

12 Pimpimpi

13 Pithaaki

14 Puka-tharaa

15 Pumpu-puru

16 Punpirr-kirran

17 Punpirr-puwan

18 Puru pinytyi-la-nhi

19 Thalaynytyaa

20 Thantaay pumanaarra

\section{Thirrama-puwan \\ 22 Waa-puru}

23 Warrtl-puwan

24 Wili-wurrunmiya

25 Winiyan-kupa

26 Wirrpinyi

porcupine

grass-with

Tank near Keewong

Crossroads (station)

\begin{tabular}{|c|c|}
\hline a beetle? & Out from \\
\hline & Murrumbong \\
\hline a creeper?-with & Out from \\
\hline & Murrumbong \\
\hline ?-with & Near Crossroads, near \\
\hline & Carowra \\
\hline & $\begin{array}{l}\text { A government tank } \\
\text { and gypsum deposit }\end{array}$ \\
\hline & ' $7 \mathrm{~m}$ from Trida' \\
\hline & Near Trida \\
\hline dead, rotten-? & Murrumbong area \\
\hline ?-balls & \\
\hline crooked-big & An unlocated place \\
\hline one & $\begin{array}{l}\text { called after a 'big old } \\
\text { bended tree' }\end{array}$ \\
\hline crooked-with & Tank between \\
\hline & Keewong and \\
\hline & Yallock; closer to \\
\hline
\end{tabular}

balls clashed Tank on Keewong or (with each Kaleno

other)

Dam near Keewong and swamp with camping areas

frogs getting Tank and well half a killed mile off the railway track, out from Trida on the Ivanhoe side

$\begin{array}{ll}\begin{array}{l}\text { hills-with } \\ \text { so there's- } \\ \text { (the) balls! }\end{array} & \begin{array}{l}\text { Near Corinya } \\ \text { hornets-with }\end{array} \\ \begin{array}{ll}\text { Irish Loonaburra } \\ \text { lips-? }\end{array} & \begin{array}{l}\text { Out from Trida } \\ \text { ?-cooba tree }\end{array} \\ & \begin{array}{l}\text { Just out from Irish } \\ \text { Lord(s) } \\ \text { Tank on Keewong }\end{array}\end{array}$

2 Ngiyampaa places with the same name? Unlikely, because Archie King gives Munnkatha for Crossroads Stn

Swamp of 'Old Parkes' (Beckett 1957) Swamp of 'Old Parkes' (Beckett 1957)

According to Liza

Fred Biggs sang a song Kennedy the name refers about tracking the son of to an old crooked tree a boundary rider, Jim Robertson, who got lost out from W-Tree and 'trotted straight through to Punpirrpuwan'

Song about the train coming to Thantaay pumanaarra in 1919 (Donaldson 1980:335). People camped there during the flu pandemic

wurrunmiya has the form of a present tense verb

Swamp of 'Old Parkes' (Beckett 1957)

Liza Kennedy's birthplace. 'Uncle Red Tank always put his hand on my head and called me nothing but that' 
Table 4: Ngiyampaa names reconstructed by Ngiyampaa people with the help of Cameron (1899)

$\begin{array}{llll}\begin{array}{l}\text { Ngiyampaa } \\ \text { name }\end{array} & \begin{array}{l}\text { Literal } \\ \text { meaning }\end{array} & \begin{array}{l}\text { Pronunciation of } \\ \text { equivalent name }\end{array} & \begin{array}{l}\text { Spelling of } \\ \text { equivalent name }\end{array}\end{array}$

1 *Murrupa-ra

thunder-s /mə'rupa/

2 *Punan or

*Punan-puwan

dust

dust-with

/ba'nuna/

3 *Putumil

4 *Wiiny-tyalapaa

firewood-

without
Bonuna

Marooba

Coombie

[part of?]

'Conoble'

(Beckett 1957)

\section{Comment and information}

'Marooba. Like thunder'. (Cameron 1899). Liza

Kennedy comments 'panturr murrupara means 'the thunder is making its noise' 'Boonoona. White ground' (Cameron 1899). Liza Kennedy comments 'White dust coming up off a clay sort of ground'

'Coombie. A sort of drum used to decoy emus' (Cameron 1899)

'Wee-in-jellebah. A camp where wood was scarce' (Cameron 1899). Liza Kennedy gives anglicised pronunciations without recognising their Ngiyampaa source 


\section{NGIYAMPAA AND THE NEWCOMERS' NAMING PRACTICES}

\subsection{Which names get anglicised equivalents?}

Major Thomas Mitchell, New South Wales' first Surveyor-General, responsible for the policy of perpetuating convenient Aboriginal names, had this to say in his instructions of 1851 about how to use them:

Map names, though derived originally from Aborigines, are for the use of Englishmen and once adopted it matters little what they mean. Our use of them, when they fit our mouths, is to distinguish geographical features. (in Heathcote 1965:34)

How does the newcomers' use of them to 'distinguish geographical features' sit with Ngiyampaa naming practices?

It will be clear from a glance at the 'Literal meaning' columns of the tables that analysable Ngiyampaa placenames do not as a rule make reference to a geographical feature, X Lake, $\mathrm{X}$ Hill and so on. There is one exception, Malka ngurrunha 'Mulga crabhole' (T3, 6). There are also occasionally names that describe a place as having certain geographical characteristics, e.g. Thirramapuwan, 'There is/are hill(s) here/there' (T3, 21), in the same way as others have certain plants (Warriyarrpuwan, $\mathrm{T} 1,43$ ) or other characteristics. The principle is to characterise the places in terms of something there, or some event associated with the place (Thantaay pumanaarra, T3, 20), rather than to give whatever feature is there a name, (like 'Here be dragons' rather than like 'Dragon Lake'). Hence the general absence of feature specifications for anglicised names in the tables' pronunciation, spelling and location columns. The Ngiyampaa people giving what they recognise as pronunciations 'in the whites' of their own names use them in their own way, regardless of whether the anglicisers have attached environmental or built-feature specifications to them or not. (Reminiscing about their days camped at 'old Carowra', they would of course include a built-feature name when talking specifically about, say, the sinking of Carowra Tank, or the likelihood of its running dry, the Aborigines Protection Board's reason for moving 'the Carowra (Tank) mob' to Menindee in 1933.)

The majority of recorded names whose geographical reference is known denote swamps or other water sources that were central to the Ngiyampaa way of life (see, for instance, the 'Significance of place' columns at Tables 1 and 3). These were precisely the places the newcomers were interested in mapping and using to establish themselves and their pastoral regimes. For contemporary corroboration 'in the Lachlan district', see Donaldson (1985b:77). A 'Map of New South Wales showing stock routes, tanks, wells, and trucking stations by D. Macdonald, CE, MGSA' published in 1888 marks only three names in the ngurrampaa: 'Paddington' (station), 'Balarambone Mt.' and 'Corowra swamp', later the largest government tank in the ngurrampaa (Kirraawara T1, 7). As the newcomers built homesteads, made tanks and drilled bores, these additional features tended to be named after the Ngiyampaa names of the swamps they were dependent on or closest to. The non-physical areal colonial subdivisions of the land - paddocks, stations as shown at Map 3, runs, leases, and parishes - might likewise be named after salient swamps and water sources within them. Figure 1 shows all the names listed on one map, Neckarboo, together with the physical features they mark, and all the parish names. The map sheets themselves, and the larger areal entities, such as counties, shires and electorates, might also end up with homestead or property names based on water source names: thus Calare electorate and an eponymous 
pastoral station both get their names from Kaliyarr, the Wiradjuri and Ngiyampaa name for the Lachlan River.

Regardless of whether the name anglicised was a swamp name, or whether the name was replaced with a different equivalent, a Ngiyampaa name could end up being represented by equivalents at several spots on a map, each being the location of a different cartographic feature: the two dots in the bottom left corner of the 'Neckarboo' part of Map 2 indicate different physical features, a homestead and a tank, both named by an equivalent for Mantyaakata $(\mathrm{T} 1,15)$, one based on the Ngiyampaa name, one quite different.

Gedda Aklif (1999:127) warns at the start of her Bardi placenames inventory: "there were no resources available to ascertain the precise location and boundaries of these places', and writes the names on her Bardi only maps without any dots. Nor have there been any such resources here. The presence of dots in association with Ngiyampaa placenames on Map 2 in this study should not be taken as any sort of precise location of the scope of reference of the Ngiyampaa names in traditional Ngiyampaa usage any more than the use of Ngiyampaa derived names for, say, parishes should encourage people to imagine that the scope of the original Ngiyampaa names' reference conformed with parish or any other introduced boundaries. We are dealing with the mapping of equivalent names, not of identically conceived places.

\subsection{Which names get replaced by what different ones, when?}

Roughly three out of every five equivalents 'in the whites' for Ngiyampaa names are based on the Ngiyampaa names made to 'fit [English-speaking] mouths'. But the creators of the remainder had other priorities than using pre-existing local names. Sometimes they chose names on grounds whose history will not be explored here, as with Wing Ding (T1, 7), defined by the Macquarie Dictionary as 'colloq. a wild party' or Irish Lords (T1, 13). Often they identified a feature such as a tank in terms of a conventional range of widely used kinds of characteristics - McDonald's, Blue, Mountain, Scrubby, Nine Mile, Lambing and so on. But as often, and more importantly for this study, they chose pre-existing placenames originating elsewhere.

Map 1 shows the four most significant camping places in the lives of the Ngiyampaa people who participated in this placenames study. Map 2 shows how in 1975 some local features, but none of the homesteads at these places, are named by anglicised versions of their Ngiyampaa names, Pamirri (T1, 30), Yakarraray (T1, 47), Kunampityaal (T1, 11) and Kirraawara $(\mathrm{T} 1,7)$.

Some of the introduced names are British placenames, typically already in use elsewhere in Australia (e.g. Paddington T1, 22). One is French, Amiens, associated with the 1914-18 World War $(\mathrm{T} 1,36)$. Some are names of places elsewhere in Australia 'derived originally from Aborigines' there (e.g. Yallock, from Victoria, T1, 28). 


\section{Place Names}

Belarabon (Hills)

Belarabon Tank (\& Wind Pump)

'Berangabah' Homestead

Berangabah Tank

Blind Creek (Intermittent)

Bullbi Tank

Campbells Tank

Collins Swamp (Perennial)

Keewong Well

'Kiama'

Kolstad Bore (Wind Pump)

'Koonaburra'

Kulki Bore (Wind Pump)

'Kulwin'

Mailbox Tank

Mirrabooka Bore (Wind Pump)

Munjagadah Tank

'Mount Doris'

'Neckarboo'

Red Swamp (Intermittent)

Sammys Bore (Wind Pump)

Sandy Creek (Intermittent)

'Tasman'

Tergarenara Tank

Timonga Lake

Tomki Tank

'W-Tree'

W-Tree Bore (Wind Pump)

Wallywigram Tank

'Yallock'

\section{Parish Names}

BARCHAM

BERANGABAH

BURRINGANNI

BURRINYANNI

COORUBA

FINLEY

GOONABURRA

KOORINYA

MARRIBUTA

PINGUNNIA

TEMOUNGA

WALLA WIGRA

YALLOCK

Notes:

1 All underlined names are spellings of names said by Ngiyampaa people to be equivalents 'in the whites' of names in Ngiyampaa, either anglicised versions of the Ngiyampaa name or changed names.

2 Note the number of names of likely Aboriginal origin, especially parish names, which Ngiyampaa people did not recognise as versions of Ngiyampaa names or as names of familiar places, despite many exploratory pronunciations, and discussions of the area. 
When the names have been 'derived ... from Aborigines' from neighbouring groups and transported only a short way, there is room for considerable confusion of various kinds unless the history of both derivation and bestowal is available, as it is in the case of Murrumbong (Kunına, T1, 14). There are two other names 'in the whites' that end in 'ng', representing a sound permissible word-finally in neighbouring Wiradjuri but not in the Wangaaypuwan Ngiyampaa of my teachers: Yathong and Keewong. Here too we should beware, in the absence of the history of bestowal, of simply assuming that these places both had different Wiradjuri names as well as Wangaaypuwan Ngiyampaa ones. Yathong (a State Forest not marked at Map 2, and homesteads) for Yaarrali $(\mathrm{T} 1,46)$ is also the name of a homestead in Queensland, but I have no proof of any connection in either direction. Even quite elaborate linguistic evidence may be inconclusive without the bestowal story, as with Keewong for Yakarraray (T1, 47). Is Keewong, said to mean 'Where the moon camped', a name based on a spelling of the Wiradjuri version, recorded from a Wiradjuri speaker, of a Ngiyampaa word for the (full?) moon, kiwaay? Or is 'Keewong' based on truncating the locative form of this word, kiwaayngka, meaning 'at' or 'by' the 'moon'? R.H. Mathews (1904:358-361) recounts a 'Wongaibon' story about 'Giwa' the moon, 'a corpulent old man', prevented by two young men from climbing an (unlocated) rock they had magically raised 20 feet. Brad Steadman (pers. comm. 2000) points out that the (1904) Ngeumba [sic] vocabulary in which Mathews gives 'wongaia' (wangaay) for 'I don't think so' (i.e. 'no') and 'giwir' for 'moon' was compiled at least in part through correspondence with the policeman at Byerock north of Cobar, D.H. Wilson. Wilson consulted half a dozen named Aboriginal people locally, of whom Billy Coleman was the authority from whom the others insisted he should learn. Pilaarrkiyalu speakers of Wangaaypuwan Ngiyampaa, in my experience, as opposed to the people from further north, from whom Mathews most likely learnt the story, use kapataa for 'moon' and kiwaay to refer to puntay kiwaay 'kneecaps' and to grindstones. For my teachers' comments on parts of this vocabulary as possibly from the 'Brewarrina mob', see Donaldson (1980:8). Brewarrina is even further north, but was also a town with a 'mission' to which many people from elsewhere went or were sent.

\subsection{Which names get ignored by newcomers?}

While roughly three in five equivalents 'in the whites' for the almost 60 Ngiyampaa names listed at Tables 1 and 2 are based on the Ngiyampaa names, nearly 30 more Ngiyampaa placenames, listed at Table 3, have no such equivalents that my teachers could remember. If there were any based on the Ngiyampaa names, interaction involving their use was insufficient for Ngiyampaa people either to learn or to remember them. I have not systematically searched old sources for likely candidates. Nor have I searched for anybody more knowledgeable about English speakers' placenames locally, in case there might be someone with a focus on equivalents 'in the blacks' as strong as the Ngiyampaa speakers' focus on equivalents 'in the whites'. What Table 3 does show is that these 30 Ngiyampaa placenames at least had an independent life of their own for Ngiyampaa people of my teachers' generation. The existence of equivalents 'in the whites' was not an essential part of how they learned or remembered them. 


\subsection{Which names get forgotten by Ngiyampaa people?}

Figure 1 shows names of likely Aboriginal origin which Ngiyampaa people were unable to recognise. There is no way that their derivation can be pursued further without extra information. Of more interest is Table 4 where Cameron's (1899) etymologies open up the possibility for Ngiyampaa people to propose Ngiyampaa forms that may have been the later forgotten basis for anglicised placenames. Until Liza Kennedy had the opportunity to back-translate Cameron's etymology, no-one imagined that *Puumpil might underlie Coombie $(\mathrm{T} 4,3)$. But in fact only two quite common mishearings need to be assumed in order to establish a link between *Puumpil and Kuumpi (as Coombie would be spelt Ngiyampaa fashion) - a final $l$ not heard, and a peripheral stop consonant made at the front of the mouth, $p$, mistaken for one made at the back, $k$.

The 'Comment and information' and 'Significance of place' columns in the tables give glimpses of a limited range of mainly ancestral Ngiyampaa linguistic and cultural values and show how ceremony and song-making conventions provided traditional mnemonics for remembering swamp and other placenames. The first contact period was one of life-threatening as well as cultural practice threatening upheaval, as people had to fit in with or dodge the re-organisation of their country and the disorganisation of their lives by outsiders. Their routes, easy camping and hunting places and means of survival all changed, and with them the numbers and kinds of people who survived where. The Marfield, Keewong and Trida mobs are known by the introduced names of the stations, never by the Ngiyampaa names of the places, which suggests they are localised social groupings formed after the pastoralists' arrival. The Aborigines Protection Board intervened, taking censuses and distributing rations from certain places (Map 3), and later institutionalising the three mobs together with a manager, first at Carowra (a reserve from 1909), then outside their ngurrampaa at Menindee in 1933 (Maps 1 and 2). We can only guess at the total impact all this may have had on previous Ngiyampaa knowledge of Ngiyampaa places and Ngiyampaa use of Ngiyampaa placenames - and on how earlier generations understood their ngurrampaa. But a contemporary song about going to Kuulankirran $(\mathrm{T} 1,13)$ to be counted in a census kept that placename alive, and gives a sense of the times. John King ('Tap') described it as paapimpaangku kuthi, a 'song of his (classificatory?) grandfather's', when he sang it for Luise Hercus in the 1960s (Archive tape 1595, side 2 item 8, Australian Institute of Aboriginal and Torres Strait Islander Studies). Archie King helped me establish the following basic text for this performance. For the poetics and performance conventions associated with such texts, see Donaldson et al. (1998).

$\begin{array}{lll}\text { Kuulankirran-ku yaay! Ngathi-tyan=likii } & \text { nganaay. } \\ \text { K.-DAT } & \text { thus } \quad \text { in.that.(place)-LING.EVID=1OBL+DU } & \text { that.way } \\ \text { So! They say (they want) us (to go) up there, to Kuulankirran. } & \end{array}$

Minya-ngalmayng-kaa mayi ka-ra? what-QUANTITY-IGNOR person be-PRES

How many people are there?

$\begin{array}{lll}\text { Yingkal-may-kalay } & \text { marrayipiya } & \text { mayi! } \\ \text { same-QUANTITY(as fingers held up)-only } & \text { old } & \text { person }\end{array}$

Just a handful of old people! 
$\begin{array}{lll}\text { Purraay-tya-la-kalay } & \text { pungku } & \text { wii-nya. } \\ \text { child-LING.EVID-THEN-ONLY many } & \text { sit-PRES }\end{array}$

Supposed to be just a lot of kids now living (there).

Kurrum-pi-kirri-piyal ${ }^{1} \quad$ nganaay maying-ku. go in-BEHIND-PURP-CONT that way person-DAT We gotta keep going, go in after, together with the people.

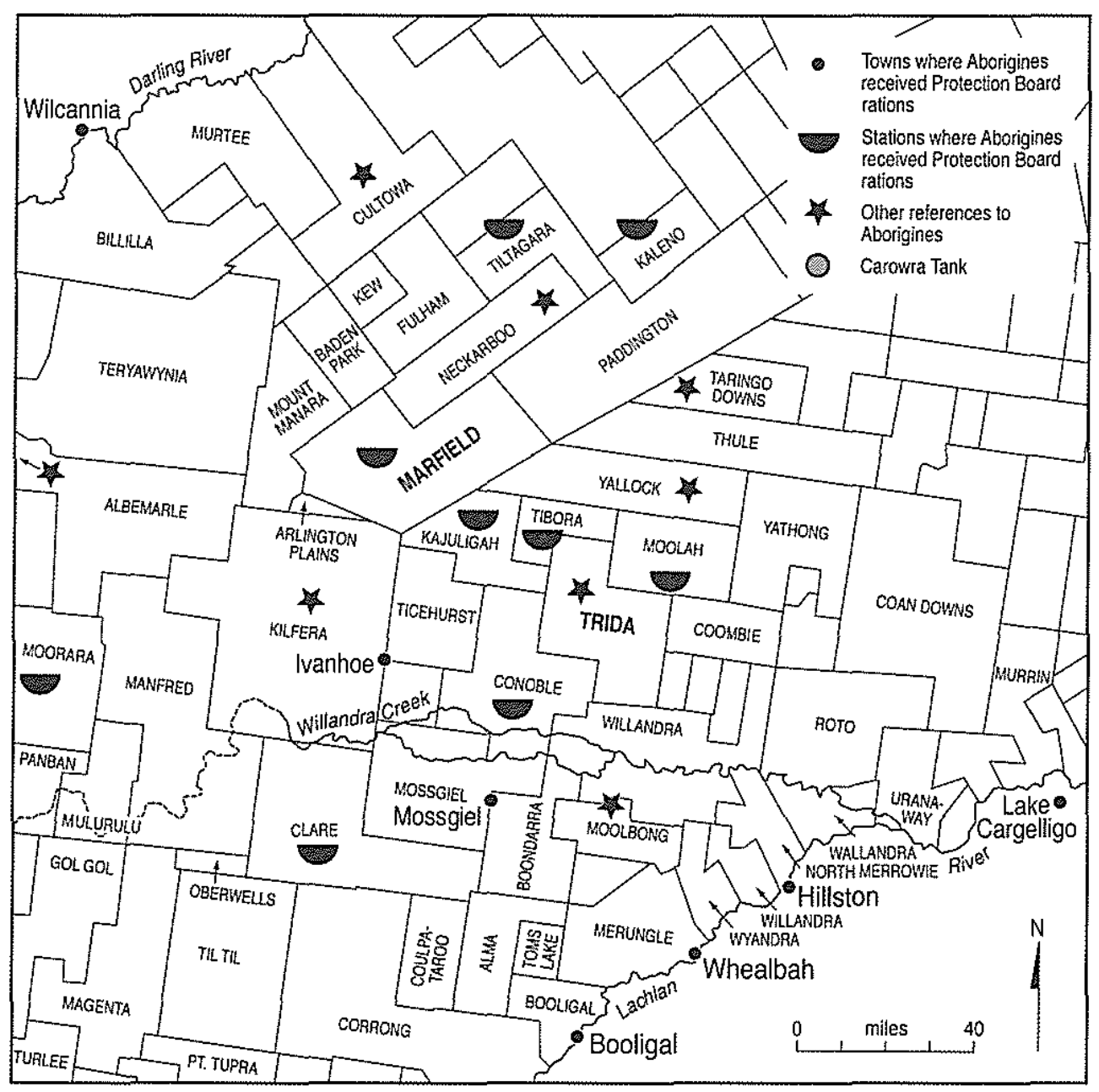

Map 3: Aboriginal people in the north-eastern Willandra Creek area, 1883-1915, as mentioned in Aborigines Protection Board records. Reproduced from part of Figure 8.1, Hope et al. (1986:109), designed by Jeannette Hope and used with her permission. Cartographer: Kay Dancey

\footnotetext{
The more usual Ngiyampaa form for -piyal, used a lot by Wiradjuri speakers, is -ngila.
} 


\subsection{Are there new Ngiyampaa names and places?}

Some of the new English placenames were taken back into Ngiyampaa for instance Puraantam (T1, 35), and Paympulaat (T2, 3), taught me by Mamie King, the youngest of my main teachers, who was born at Paympulaat in 1918 or 1919.

It is not always immediately clear which way the traffic went. Yurruutu is predictable as a Ngiyampaa version of Roto (T1, 48). But could English speakers have failed to hear the initial $Y u$ - when anglicising Yurruutu? How did the name Roto (with one gazetted occurrence in Queensland) arise? Also, compare Karraapu (T1,2) and Wiinytyalapaa (T4, 4). One Ngiyampaa and one imported name for the same place? Could Canoble be a pre-existing placename transported from somewhere else, provoking the possibly originally joking etymology Karraa-pu 'Wait on!' given by Manny Johnson? Or were there two close Ngiyampaa places with two Ngiyampaa names selectively remembered by different Ngiyampaa people? This is simply more likely, on the negative evidence that there is no Conoble or Canoble gazetted elsewhere in Australia in the first Australia-wide gazetteer, based on the 1975 CMA 1:100 000 map series used in this study.

Puraantam and Paympulaat retain the English final consonants $m$ and $t$ of Browns Dam and Pine Flat, not normally permissible word-finally in Ngiyampaa. Other consonants in anomalous positions, however, are not the result of recently taking English names into Ngiyampaa. The otherwise unknown sequence $n n g$ in Kirranhannga $(\mathrm{T} 1,8)$ can be taken as a sign of the probable antiquity of the name (Donaldson 1980:48).

There is a range of other, non-phonotactic, evidence for the antiquity of many of the names. This includes the lack of evident literal meaning for many of them, even when they contain intelligible parts (e.g. T1, 17), or grammatically recognisable forms (T3, 24). There are inherited stories from, literally, 'absolutely long ago' (marrathal-pu) linked to some places. Waaway was killed at Yaarrali (T1,46) (Donaldson 1980:317). Eagle took water to the sky from Pamirri (T1, 30) (Berndt 1947:81-82). Other such stories may explain why some of the literal meanings are as they are. A widely known story survives with versions in which Porcupine drops a talking turd (Donaldson 1980:319-322). Did this happen at Kunampityaal (T1, 11)? (Cameron, by contrast, with his 1899 interpretation: 'Koonamgal. 'Dirty place (a lot of dung about)' [sic], seems to have thought the place so named or newly renamed because of striking changes brought about by introduced animals.) There are also names with narrative meanings without remembered fuller stories to explain them. Who, for instance, are the 'Frogs getting killed' at Thantaay pumanaarra $(\mathrm{T} 3,20)$ ?

Also, are all the names alluding to the plant world of equal age? Punpirrpuwan refers to a particular crooked tree (T3, 17), Muumpalpaa to a prevalent species (T1, 24). Patterns of vegetation alluded to in some of the names would have remained basically stable, depending as they did chiefly on the underlying geology until some ecological changes began as a result of radical changes in land use, such as those leading to the listing of the Acacia loderi [nelia] Shrublands, with 'major stands' near Ivanhoe, as an endangered ecological community under the New South Wales Threatened Species Conservation Act 1995 (New South Wales Government Gazette No. 131, 6 October 2000: 10957-8). The group names by which the Wangaaypuwan Ngiyampaa designate themselves, as 'nelia tree', 'belar tree' and, further north, as 'stone/rock' people (Donaldson 1984), are consonant with gross differences in the underlying geology of their groups' traditional areas in so far as these areas are known. There is no reason why this principle of basic stability of significant vegetation depending on underlying soil structure should not apply on smaller scales too (Victor Gostin pers. comm. 2000). The issue could be pursued with the help of the land system map series whose sheets 
correspond to the 1:250 000 CMA topographic maps. These maps integrate the representation of geology, soils and vegetation. A useful source of very detailed vegetation information from early pastoral days in the ngurrampaa is the pastoral leasehold area maps of the Western Lands Commission, one of which is reproduced as Map 4. The types of tree and plant they indicate belong to the same range that occurs most frequently in the Ngiyampaa placenames.

While most of the placenames may be of a great age, many of the principles of placename formation are quite transparent, at least on a grammatical level (see \$2.2). The analysable suffixes involved are highly productive elsewhere in the language, readily recognisable and available for use in the creation of new placenames (Donaldson 1980, especially Chapter 4). Did Ngiyampaa people keep creating new names, for instance in response to changes wrought by the newcomers? Or simply make a few English ones 'fit [Ngiyampaa] mouths'?

Table 4 shows Liza Kennedy not creating, but reconstructing, a placename in a time-honoured way, proposing *Punanpuwan as a possible source for $(\mathrm{T} 4,2)$. The comitative suffix - puwan 'with' is also translatable as 'having', '(It) has', 'There is/are X (there)' etc. It is the most widely used suffix not only in placename formation but in name formation generally. The language name Wangaaypuwan means literally 'no-with', that is '(the language) with wangaay as its word for "no". More relevantly, -puwan was still being used in the formation of personal nicknames during the period that I was learning placenames (King 1990). We have already seen how a birthplace placename could become a personal name (Wirrpinyi, T3, 26). When people adopted English-style forenames and surnames, they often continued to use or be referred to by placenames as surnames. Liza Kennedy, born at Wirrpinyi, like many of her relations of the Keewong mob, took the maiden surname Keewong. She also appears with her sisters in a 1909 list of Ngiyampaa children in need of schooling (Kabaila 1996:98) with the surname Yallick [sic] (T1, 28). And some people's nicknames continued to reflect birthplaces $(\mathrm{T} 2,4)$ and names of places with which people had other associations. Were people creating new placenames too?

People were on occasion creating etymologies with recent reference. In Ngiyampaa, yathara means '(It) is sticking'. Ida Singh said she had been told a place (outside her own ngurrampaa), which I had found spelt 'Yathara' on a local map, had been named when a whitefella asked a blackfella to open a gate and the blackfella answered: 'Yathara!' Was the place with a defective gate already a place before it got a gate? In other words, would it help to rephrase the question, 'Were people creating new placenames?' and ask: 'Were Ngiyampaa people creating or recognising new places?'

Ad hoc descriptions of spots using placename formation stratagems, like adding -puwan to a characteristic of the place, were plentiful when I went hunting with my teachers. On one occasion Sarah Johnson built a tiny nganu (which she translated 'miamia') to show me how. Ten years later a group of us chanced on it again, still intact. Thereafter, discussing where to go hunting, we might orient ourselves in relation to nganum-puwan 'miamia-with'. I imagine it was ever so, that there were fleeting ad hoc names for places of temporary importance to small numbers of people. Some early surveyors, according to Heathcote (1965:34), appear to have formed the impression, no doubt for a variety of other reasons as well, that Aboriginal placenames were often unreliable 'ephemeral titles ... changing from year to year'. Mapmakers have to have formal processes for deciding what is a place for a given map, what constitutes a name worthy to begin with a capital letter. The main method available for compiling the tables presented here, comparison of Ngiyampaa recollections and recent practices with names on newcomers' maps, gives us only partial insights into the full social meaning of places and place naming for my teachers' forebears in an all-Aboriginal world. 


\section{TIBORA HOLDING}

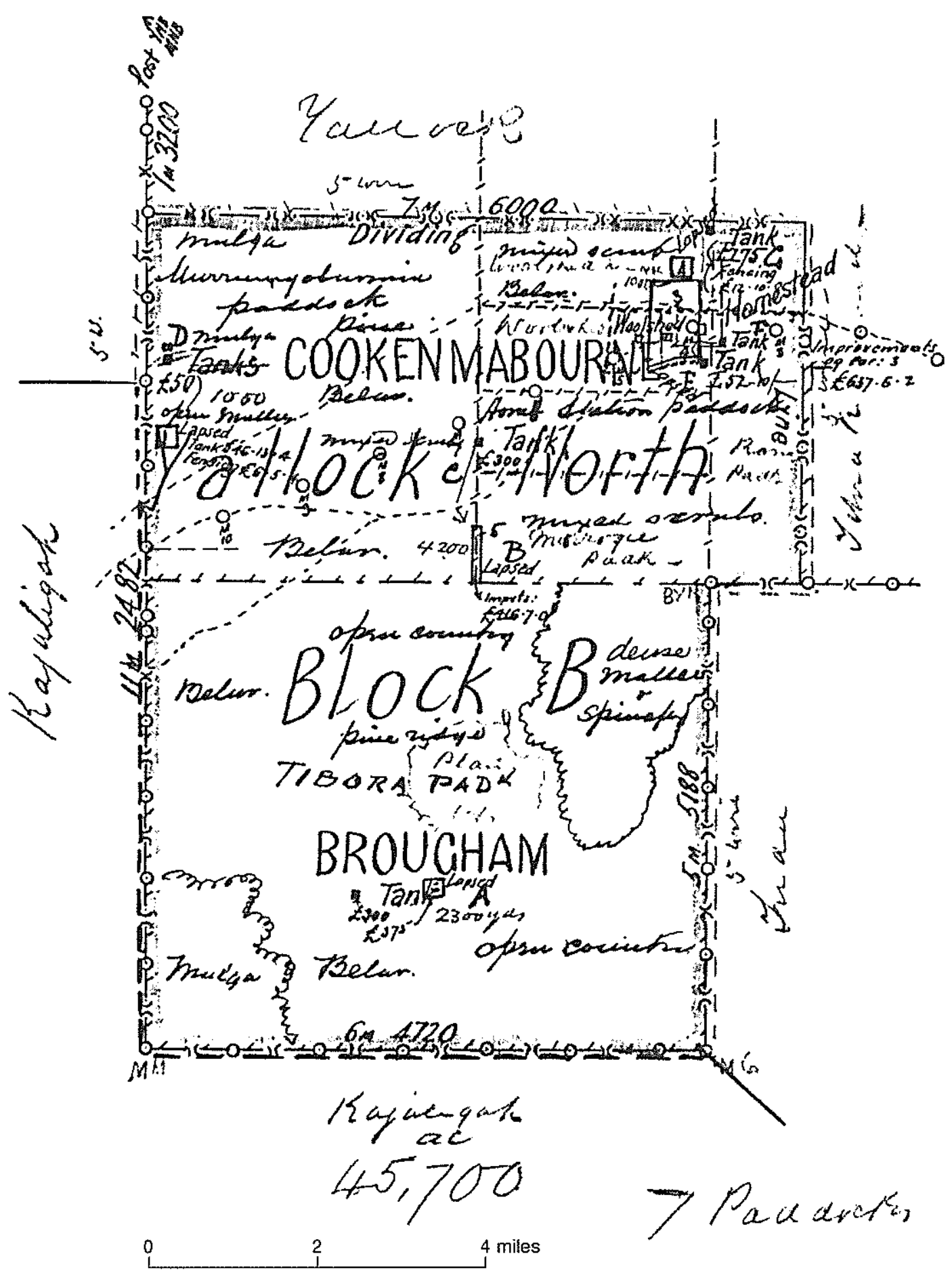

Map 4: Leasehold area plan, Tibora Holding, showing pre-1901 placenames and vegetation. Reproduced from the original map in State Records New South Wales: Western Lands Commission: Pastoral Lease Files CGS 14570. (SRNSW ref: 10/43877). Land District: Hillston North, Leasehold Area: Tibora, Lease Number 150, with the permission of State Records New South Wales. 


\section{RELATIONS BETWEEN NGIYAMPAA NAMES AND THOSE BASED ON THEM}

\subsection{Can we predict from the form of Ngiyampaa names how they might be anglicised?}

The answer is yes, but only when the Ngiyampaa name already 'fits [English] mouths' so closely that the impact of 'making them fit' is only to introduce a hint of an English speaker's 'accent'. It is hard to see how Mula $(\mathrm{T} 1,21)$ could have been heard or pronounced by English speakers in any other way than it has been. Each of the sounds involved corresponds to a single phoneme in English (both $u$ in this stressed position and $u u$ get interpreted as the 'oo' in 'moon' rather than 'book'). The phonotactics are fine in English, so is the stress placement on the first syllable. This means that there are unambiguous ways of spelling it according to English spelling conventions, so that it will be read by those who have never heard it said in exactly the same way the writer intended. It could have been spelt Mooler instead of Moolah, but that might have encouraged interpretation in terms of a verb to 'mool' or an adjective 'mool' rather than as a conventional name with a final vowel like that in Dinah or Kogarah. The spelling 'moolah' also represents an existing colloquial English word for 'money' with its own entry in the Macquarie Dictionary, a mnemonic for the pronunciation of the name regardless of whether users are also aware of the word's (Ab)original meaning.

By the same token, spelling the name 'Mula', using the phonological spelling system devised for writing Ngiyampaa, could have consistently resulted in the same pronunciation when read aloud by English speakers, unless they chose to pronounce the ' $u$ ' as in 'mute' rather than like the 'oo' of 'moot'.

The moment any of these formal coincidences between Ngiyampaa and English does not apply, any one of a range of things may happen at each stage of converting the name hearing, saying, writing, reading - with each choice leading to a different range of possibilities at the next stage, perhaps responded to differently by different participants in the processes involved. To make matters more complex the 'stages' are of course not likely to occur in a strict linear progression but to loop back, with each repetition of a stage able to influence each of the others, though 'once adopted' as map names, the pronunciations in Aboriginal languages of Aboriginal placenames have usually mattered as little as 'what they mean' did according to Mitchell. The fate of Kityuulitya $(\mathrm{T} 1,9)$ includes confusion resulting from competing pronunciations, with a reading pronunciation of the map spelling conflicting with, and gradually gaining ground on, the pronunciation in local oral tradition, which is much closer to the Ngiyampaa one.

A game to enable people to explore the effects of these trickier anglicisation processes is described in Donaldson (1995). A version of it was played at the Adelaide placenames meeting at which versions of some of the papers in this book were first presented. The idea was to mimic extreme situations requiring impromptu decision making on the part of lone individuals in the writing of Ngiyampaa names using English spelling resources and in the pronunciation by other lone individuals of the names thus written. I asked people to imagine themselves as builders of the first homestead at a Ngiyampaa place, paintbrush in hand to write its name on the gate, asking a passing (non-literate) Ngiyampaa person to say the local placename for them and painting it on. I acted the passer-by, dictating a name from Table 1 , which they wrote on slips. Later I asked them to imagine themselves metropolitan radio announcers without pronunciation research help, reading news of a rural tragedy occurring on a pastoral station whose name is appearing before them for the first time, in writing only. They each picked a slip (not of their own writing) and pronounced what they saw written 
there. There were very few identical spellings. And there were even fewer identical readings, whether of the same or different spellings of the one name.

I chose Karrarra (T1, 3) and Kirraawara (T1, 7) as names to dictate because their anglicised pronunciations today are so close that they are frequently confused. The anglicising switch of stress from the first to the second syllable of Karrarra and the maintenance of the Ngiyampaa stress on the long second syllable of Kirraawara has meant that the first vowel in both names has been pronounced by English speakers as unstressed English /a/, then written ' $a$ ' (Karrara, Carowra), which in turn continues to get read as $/ 2 /$. However, the only thoroughly consistent result of the game was that all the painters of names on gates, without exception, having just listened attentively to the Ngiyampaa pronunciation, chose the spellings ' $a$ ' or ' $u$ ' and ' $i$ ' respectively to write the vowels in the first syllables of Karrarra and Kirraawara.

Sometimes anglicisers will stabilise the pronunciation of their spellings by using the spelling of a similar-sounding English word, thereby sometimes masking the word's Aboriginal origin, provided the word chosen does not attract too much attention by its bizarreness in the contexts in which it is used. Ngiyampaa warriyarr appears as 'warrior bush' as well as 'currant bush' in Cunningham et al. (1981:337), giving rise to little change in pronunciation except anglicisation of the first $r r$ to $\mathrm{r}$, and loss of the second. The comitative suffix -puwan 'with' appears as an English placename element '-bourne' as in Melbourne, intended to be pronounced the Queen's English way, presumably, in Cookenmabourne (Map 4) for Kukumapuwan $(\mathrm{T} 1,10)$ and as '-bon' or '-bone' commonly elsewhere (amongst other spellings).

But sometimes the effect of 'Ngiyampaa whispers' and its orthographic counterpart appears to have so overwhelmed the angliciser that the result looks and sounds like an act of flailing panic. The anglicised version of the placename Warriyarrpuwan $(\mathrm{T} 1,43)$ is nothing like Warriorbourne. It is written, unpredictably, 'Wallwera' and, in a probably later form, 'Walewira'.

\subsection{Can we reconstruct from the form of anglicised versions what the original Ngiyampaa name was?}

Faced with the spelling 'Wallwera' and no other information except how it is pronounced, what are a linguist's chances of reconstructing a source form *Warriyarrpuwan? Much like a Ngiyampaa speaker's when asked what the Ngiyampaa name for the place with the map name Bonuna is before hearing that A.L.P. Cameron had published a meaning for it in 1899. Liza Kennedy, given the meaning, suggested *Punan or *Punanpuwan $(\mathrm{T} 4,2)$. Given a meaning involving 'wild currant bush' or 'warrior bush', a speaker or a linguist with a dictionary and a familiarity with placename formation strategies in Ngiyampaa could offer a similar pair of possibilities *Warriyarr or *Warriyarrpuwan. If we look at Wallwera as an attempt to represent Warriyarr, it suddenly becomes quite easy to deduce what has probably happened. Its spelling involves exactly the same difficulties in representing $r r$ sounds as the 'warrior' spelling does. It looks as if the first to write the name have recognised that there is something un-English about the first lateral sound $r r$, so that they have started writing ' 11 ', and have added a ' $w$ ' to account for its strangeness. Likewise, they have added a neutral final vowel ' $a$ ', to make sure that the strange final $r r$ (usually voiceless and sometimes described as 'whistled' in this position) is also pronounced - but as $/ \mathrm{r} /$, rather than being dropped altogether as in the Australian-English pronunciation of 'warrior'. 
Comparison of the two spellings 'warrior' and 'Wallwera' alone, without access to the source form warriyarr, but with the knowledge of their pronunciations and that they both mean the same thing, could lead to a suspected original form *warriyarr. For detailed examples of how to reconstruct Aboriginal words through comparing (as many as possible) anglicised spellings, see Austin and Crowley (1995).

In this sort of work with placenames, it is important to spot and use wherever possible the anglicised spellings which look like English names. In the Araluen Valley between Canberra and the coast is an ex-Post Office. When it was opened in 1894 the name Sherarba was proposed, 'as that was the native name of the place' (Cremer nd:1). Behind it rises Shellharbour mountain. The daftness of a landlocked inland mountain being called after a harbour alerts one to the likelihood of its being an alternative attempt at making this native name in Mitchell's words 'fit our mouths'. Indeed Cremer reports that the Post Office was named Araluen Post Office because the name Sherarba was considered to be 'too similar to Shellharbour', and so, presumably, likely to cause confusion with the post office at Shellharbour on the Wollongong coast. Assuming the same inventory of phonologically significant sounds, if not the same phonotactics, for the language formerly spoken in the valley as for Ngiyampaa, and employing the spelling system used for Ngiyampaa, it is possible to suggest an original name with seven segments, with the following possibilities for each:

$$
\text { * }\left\{\begin{array}{l}
t y \\
t h
\end{array}\right\}{ }^{i}\left\{\begin{array}{l}
r \\
r r \\
l
\end{array}\right\}\left\{\begin{array}{l}
a \\
a a
\end{array}\right\}\left\{\begin{array}{l}
\text { nothing } \\
r r
\end{array}\right\} p a
$$

But one cannot plump with certainty for, say, *Thirarrpa as opposed to other possible combinations in the absence of more direct evidence from speakers. Even a few more spellings might help to constrain the generalisations in the formula. One thing, however, is certain: the original name never meant anything to do with shells or harbours.

This has been a scanty exploration at $\$ 4$ of the sound relationships, as mediated in talk and writing, between Ngiyampaa placenames and their anglicised equivalents. The material presented at the tables would allow pursuit of the topic at much greater depth. It should also be helpful to others considering reconstruction where there is less information available, or of fewer kinds.

\section{CONCLUSION}

Reacting to the way in which George Augustus Robinson recorded the personal names of the Tasmanian survivors whom he gathered up, then gave them new ones, Inga Clendinnen writes: 'Real names differentiate and connect; they have social meaning' (Clendinnen 2000:216).

We have seen how Ngiyampaa placenames, whatever the stories encrypted in their literal meanings, can provide names for people whose social meaning is to connect them as a group, via their personal histories, to their ngurrampaa. We have seen how the introduced placenames which have replaced many of the Ngiyampaa ones on maps often connect these places with other places which have been meaningful in their bestowers' lives elsewhere.

Major Mitchell may have been right that the meanings of anglicised Aboriginal placenames are irrelevant to their usefulness for cartographic purposes. But the business of 
which names get anglicised, how, and which get replaced, how, also involves the generation of all sorts of social meanings, all sorts of differentiations and connections between people and people and between people and places. Stories arise, often without reference to the history of the namer's bestowal, if known. They can be 'real' enough to their proponents to be capable of overriding strictly phonological processes in determining pronunciations and spellings. Kim Mahood tells five vividly competing stories about the naming of Mongrel Downs (later Tanami Downs), a station in the Tanami Desert of the Northern Territory (Mahood 2000:47). Her own story is that it was in fact named by Joe Mahood (her father) and his friend Bill Wilson 'as a kind of up-yours gesture' in response to local views that they "must be mad to try to create a cattle station on "that mongrel bit of country out there". She also writes that:

An artist friend in Alice who works for the sacred sites department tells me that the local Aborigines believe Mongrel is a distortion of Monkarrurpa, ... the traditional name for Lake Ruth. In a Brisbane gallery I picked up a catalogue of work by Balgo and Tanami artists, and featured in it was a work by a woman artist from 'Mongrelupa'. (Mahood $2000: 47)^{2}$

Here I have tried to show, with data from the 1880 s to the 1980 s, a century of placenames competing and collaborating to create many worlds, both different and connected, out of this western New South Wales Wangaaypuwan Ngiyampaa drylanders' 'camp-world' - as many worlds as there have been people to use these names to structure and communicate aspects of their knowledge about and relations to the land.

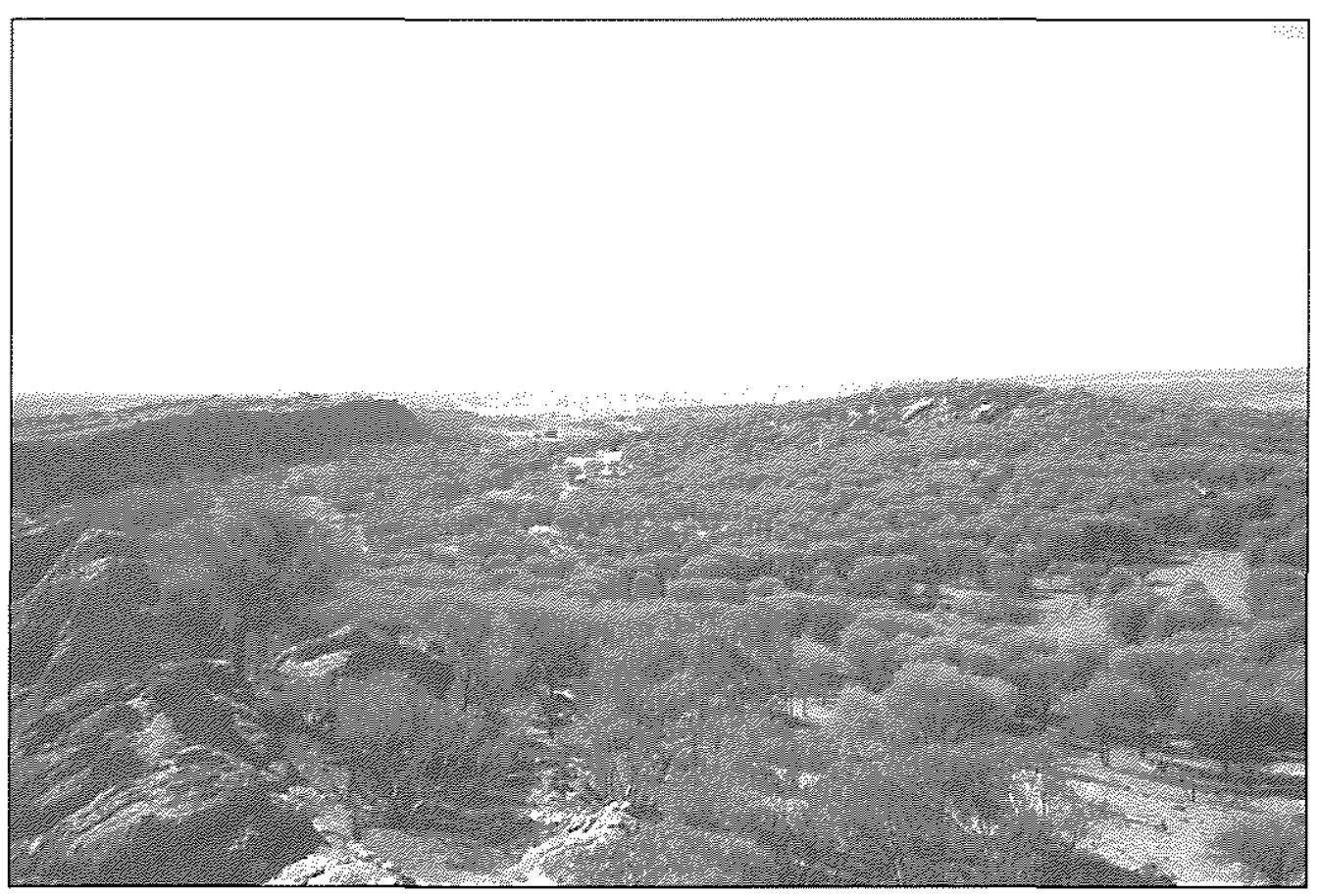

Figure 2: View of the ngurrampaa from Mount Manara, with the hills at Karrimya on the horizon Photo: Tamsin Donaldson, 1997

2 The former Mongrel Downs pastoral lease is now the Mangkurukurrpa Aboriginal Land Trust. According to the Aboriginal Land Commission (1992:18), 'Mungkururrpa [is a] Dreaming [site] close to the ... homestead'. 


\section{REFERENCES}

Aboriginal Land Commission, 1992, Tanami Downs Land Claim. Report by the Aboriginal Land Commissioner to the Minister for Aboriginal and Torres Strait Islander Affairs and to the Administrator of the Northern Territory. Report No. 42. Canberra.

Aklif, Gedda, 1999, Ardiyooloon bardi ngaanka One Arm Point Bardi Dictionary. Halls Creek: Kimberley Language Resource Centre.

Austin, Peter and Terry Crowley, 1995, Interpreting old spelling. In Nicholas Thieberger, ed., Paper and Talk: a manual for reconstituting materials in Australian indigenous languages from historical sources, 53-102. Canberra: Aboriginal Studies Press.

Beckett, Jeremy, 1957, unpublished field notebook 6 'TRAD. K.' 87pp. Manuscript.

1959, Further notes on the social organisation of the Wongaibon of western New South Wales. Oceania 29(3):200-207.

Berndt, Ronald M., 1947, Wuradjeri [sic] magic and 'clever men'. Oceania 18(1):60-86.

Cameron, A.L.P., 1899, Aboriginal names of places. Science of Man 2(10):195.

Clendinnen, Inga, 2000, Reading Mr Robinson. In Inga Clendinnen, Tiger's Eye: a memoir, 191-218. Melbourne: The Text Publishing Company.

Cremer, Vann L., n.d. Araluen post office: Brief historical notes. 3pp. Supplied in 1986 by the NSW Historical Officer, Historical Section, Australia Post. Sydney: Australia Post GPO.

Crotton, G.W. and C.B., n.d., Crotton's Australia: Entered according to Act of Congress in the year 1855. Map. 172, William Street, New York.

Cunningham, Geoff, Bill Mulham, Peter Milthorpe and John Leigh, 1981, Plants of Western New South Wales. Sydney: New South Wales Government Printing Office.

Donaldson, Tamsin, 1980, Ngiyambaa: the language of the Wangaaybuwan. Cambridge: Cambridge University Press.

- 1984, What's in a name? An etymological view of land, language and social identification from western New South Wales. Aboriginal History 8:21-44.

- 1985a, From speaking Ngiyampaa to speaking English. Aboriginal History 9(2):126-147.

- 1985b, Hearing the first Australians. In Ian Donaldson and Tamsin Donaldson, eds, Seeing the First Australians, 76-91. Sydney: George Allen and Unwin Australia.

- 1995, What word is that? A hearing writing reading game. In Nicholas Thieberger, ed., Paper and Talk: a manual for reconstituting materials in Australian indigenous languages from historical sources, 43-52. Canberra: Aboriginal Studies Press.

- 1997, Ngiyampaa wordworld 1: thipingku yuwi, maka ngiya, names of birds \& other words. Canberra: the author with assistance from the Australian Institute of Aboriginal and Torres Strait Islander Studies.

Donaldson, Tamsin with Margaret Gummow and Stephen A. Wild, 1998, Traditional Australian music: south-eastern Australia. In Adrienne L. Kaeppler and Jacob W. Love, eds, Australia and the Pacific Islands, Volume 9 of The Garland Encyclopaedia of World Music, 439-443. New York and London: Garland Publishing Inc.

Glover, H.M. (Noni), 1989, A Town Called Ivanhoe: a history. Hay: The Riverine Grazier. 
Heathcote, R.L., 1965, Back of Bourke: a study of land appraisal and settlement in semi-arid Australia. Melbourne: Melbourne University Press; London and New York: Cambridge University Press.

Hercus, Luise A., 1993, Paakantyi Dictionary. Canberra: the author with assistance from the Australian Institute of Aboriginal and Torres Strait Islander Studies.

Hope, Jeannette, Tamsin Donaldson and Luise Hercus, 1986, A history of the Aboriginal people of the Willandra Lakes Region. Unpublished report, NSW Department of Planning (now NSW Department of Urban Affairs and Planning).

Johnson, Doreen, Eva Longmore, Eliza Kennedy, Horace King, Lena Parkes and Mamie King, 1982, Ngiyampaa Alphabet Book. Dubbo: Western Region Country Area Program Western Readers. Revised ed; 1985. Dubbo: Development and Advisory Publications, Aboriginal Heritage.

Kabaila, Peter Rimas, 1996, Wiradjuri Places: the Lachlan River basin. Canberra: the author.

Kennedy, Eliza and Tamsin Donaldson, 1982, Coming up out of the nhaalya: reminiscences of the life of Eliza Kennedy. Aboriginal History 6:4-24.

King, Mamie, 1990, Text 1, page 24. In Tamsin Donaldson 'Patakirraparaaypuwan in western New South Wales', 21-27. In Peter Austin, R.M.W. Dixon, Tom Dutton and Isobel White, eds, Language and History: essays in honour of Luise Hercus, 21-27. Canberra: Pacific Linguistics.

The Macquarie Dictionary, 1981. Arthur Delbridge, editor-in-chief. St Leonards, NSW: Macquarie Library.

Mahood, Kim, 2000, Craft for a Dry Lake. Sydney: Anchor.

Malouf, David, 1985, The only speaker of his tongue. In Antipodes: stories by David Malouf, 68-72. London: Chatto \& Windus/The Hogarth Press.

Mathews, R.H., 1904, Ethnological notes on the Aboriginal tribes of New South Wales and Victoria. Journal and Proceedings of the Royal Society of New South Wales 38:203-381. 